\title{
Epigenetic therapy with inhibitors of histone methylation suppresses DNA damage signaling and increases glioma cell radiosensitivity
}

\author{
Ozge Gursoy-Yuzugullu${ }^{1}$, Chelsea Carman ${ }^{1}$, Rodolfo Bortolozo Serafim ${ }^{1}$, Marios \\ Myronakis $^{1}$, Valeria Valente ${ }^{2}$, Brendan D. Price ${ }^{1}$ \\ ${ }^{1}$ Department of Radiation Oncology, Dana-Farber Cancer Institute, Boston MA 02215, USA \\ ${ }^{2}$ São Paulo State University (UNESP), School of Pharmaceutical Sciences, Araraquara, Rodovia Araraquara-Jaú, Campos \\ Ville, SP, 14800-903, Brazil
}

Correspondence to: Brendan D. Price, email: brendan_price@dfci.harvard.edu

Keywords: DNA repair, radiosensitizer, glioma, histone methylation, G9a

Received: January 04, $2017 \quad$ Accepted: February 07, $2017 \quad$ Published: February 20, 2017

Copyright: Gursoy-Yuzugullu et al. This is an open-access article distributed under the terms of the Creative Commons Attribution License (CC-BY), which permits unrestricted use, distribution, and reproduction in any medium, provided the original author and source are credited.

\section{ABSTRACT}

Radiation therapy is widely used to treat human malignancies, but many tumor types, including gliomas, exhibit significant radioresistance. Radiation therapy creates DNA double-strand breaks (DSBs), and DSB repair is linked to rapid changes in epigenetic modifications, including increased histone methylation. This increased histone methylation recruits DNA repair proteins which can then alter the local chromatin structure and promote repair. Consequently, combining inhibitors of specific histone methyltransferases with radiation therapy may increase tumor radiosensitivity, particularly in tumors with significant therapeutic resistance. Here, we demonstrate that inhibitors of the H4K20 methyltransferase SETD8 (UNC-0379) and the H3K9 methyltransferase G9a (BIX-01294) are effective radiosensitizers of human glioma cells. UNC-0379 blocked H4K20 methylation and reduced recruitment of the 53BP1 protein to DSBs, although this loss of 53BP1 caused only limited changes in radiosensitivity. In contrast, loss of H3K9 methylation through G9a inhibition with BIX-01294 increased radiosensitivity of a panel of glioma cells (SER2Gy range: 1.5 - 2.9). Further, loss of H3K9 methylation reduced DSB signaling dependent on $\mathrm{H} 3 \mathrm{~K} 9$, including reduced activation of the Tip60 acetyltransferase, loss of ATM signaling and reduced phosphorylation of the KAP-1 repressor. In addition, BIX-0194 inhibited DSB repair through both the homologous recombination and nonhomologous end-joining pathways. Inhibition of G9a and loss of H3K9 methylation is therefore an effective approach for increasing radiosensitivity of glioma cells. These results suggest that combining inhibitors of histone methyltransferases which are critical for DSB repair with radiation therapy may provide a new therapeutic route for sensitizing gliomas and other tumors to radiation therapy.

\section{INTRODUCTION}

Chromatin organization can limit the ability of the DNA repair machinery to access sites of DNA damage. Consequently, DNA repair requires rapid chromatin reorganization to create the open chromatin structures required for DNA repair [1]. This remodeling of the chromatin is particularly important for repair of DNA double-strand breaks (DSBs), which can lead to cell death if unrepaired. DSB repair involves dynamic changes in histone modification and exchange of specific histone variants directly at the break site, as well as recruitment of chromatin binding proteins to the damaged chromatin [1-3]. Further, when chromatin reorganization at DSBs is blocked, DNA repair is inhibited and cells exhibit increased sensitivity to agents that create DSBs. Because many anti-cancer therapies, including radiation therapy, kill tumors by creating DSBs, combining inhibitors of chromatin organization with radiation therapy may provide a new route to improving overall effectiveness of anti-cancer therapy. 
The repair of DSBs is associated with significant changes in epigenetic modification of histones, including alterations in ubiquitination, acetylation, methylation and phosphorylation of nucleosomes. One of the earliest epigenetic modifications during DSB repair is phosphorylation of histone $\mathrm{H} 2 \mathrm{AX}(\gamma \mathrm{H} 2 \mathrm{AX})[4]$ by the ATM and DNA-PKcs kinases [5]. $\gamma \mathrm{H} 2 \mathrm{AX}$ recruits several DNA repair proteins, including the ubiquitin ligases RNF8 and RNF168 [6], to the break site, where they ubiquitinate $\mathrm{H} 2 \mathrm{~A}$. Ubiquitinated $\mathrm{H} 2 \mathrm{~A}$ then recruits the 53BP1 protein $[7,8]$. 53BP1 plays a key role in suppressing HR mediated repair and promoting NHEJ $[9,10]$. DNA damage also recruits several acetyltransferases, including Tip60, which acetylates histones and creates local regions of open, relaxed chromatin which favor DSB repair $[1,11]$. In addition to these modifications, it is now clear that dynamic changes in methylation of histones $\mathrm{H} 3$ and $\mathrm{H} 4$ play a central role in regulating the cells response to DSBs.

Recruitment of the 53BP1 DNA repair protein also requires methylation of histone $\mathrm{H} 4$. 53BP1 is dual chromatin reader containing a ubiquitin-interacting motif (UIM) which binds to ubiquitinated $\mathrm{H} 2 \mathrm{~A}$ and a tudor domain which binds histone $\mathrm{H} 4$ methylated at lysine 20 (H4K20me2) [7, 8]. Although DSBs may increase H4K20me2 at some DSBs [12], most of the H4 in cells is constitutively methylated by SETD8 at H4K20 [13]. Further, loss of H4K20me2 can lead to decreased genomic stability [14], indicating the importance of this modification for DSB repair. DSB repair also leads to increased $\mathrm{H} 3 \mathrm{~K} 9$ methylation on nucleosomes at the DSB $[15,16]$. H3K9me3 then recruits several repressive HP1 complexes [15] as well as the Tip60 acetyltransferase [17] to the DSB. HP1 complexes create transient repressive structures which favor repair [15, 18, 19], while Tip60 acetylates several DSB repair proteins, including the ATM kinase $[17,20]$. In addition, Tip60 (as part of the NuA4Tip60 complex) acetylates histones H2A and H4 [17, 2123], leading to open, flexible chromatin domains which are essential for DSB repair $[3,11]$. In yeast, methylation of H3K79 by DOT1L is important for repair [24] and DOT1L and H3K79 methylation are important for global genomic repair and 53BP1 recruitment in mammalian cells $[25,26]$. However, the exact importance of H3K79 methylation in mammalian DSB repair remains to be determined.

Components of the polycomb repressor complexes PRC1 and PRC2, including the PRC1 ubiquitin ligase and PRC2 EZH2 methyltransferase, are also recruited to DSBs [27-30]. EZH2, which methylates H3K27 and promotes repressive chromatin formation [29], is enriched at DSBs [30-32] and may increase local H3K27me3 $[30,31]$, although some workers reported no increase in H3K27me3 after DNA damage [27, 28]. EZH2 has also been implicated in regulating key DSB repair proteins, including rad51 [33] and p53 [34] and is associated with altered DNA damage responses. Finally, methylation at H3K36 by SETD2 is important for promoting HR- mediated repair within actively transcribed regions [35-37], indicating that dynamic changes in H3K36 methylation status are important for maintaining genomic stability.

Dynamic changes in histone methylation are therefore intimately involved in regulating the cells ability to detect and repair DSBs. In fact, inactivation of lysine methyltransferases (KMTs) involved in DSB repair, including those which methylate H3K9 (SUV39H1, PRDM2 [15, 16]), H3K36 (SETD2 [35]), H3K79 (DOT1L, $[25,26])$ or H3K27 (EZH2 [30, 32, 34]) leads to defects in DNA repair, altered chromatin organization at DSBs and increased cell death. Further, many of these methyltransferases are mutated or overexpressed in human malignancies, and small molecule inhibitors have been developed to target these misregulated KMTs [38, 39]. For example, fusions between the MLL protein and several transcription factors recruits DOT1L to gene promoters in MLL-leukemias [38], leading to altered gene expression. DOT1L inhibitors can specifically target this altered gene expression and selectively kill MLL-leukemias [40]. EZH2 is frequently overexpressed or mutated in breast, prostate lung and other cancers, and inhibitors targeting EZH2 are currently being examined as a therapeutic approach to treat these tumors $[38,39,41]$. Thus many of the histone methyltransferases which are required for DNA repair are also deregulated in cancer cells. Combining inhibitors of specific histone methyltransferases with radiation therapy may therefore increase tumor sensitivity to radiation therapy, particularly in tumors with significant therapeutic resistance. Further, using specific inhibitors in tumor cells which overexpress histone methyltransferases required for DSB repair may allow for targeted epigenetic therapy.

Here, we examined the ability of a group of histone methyltransferase inhibitors to sensitize a panel of glioblastoma (GBM) cell lines to radiation therapy. GBM is the most frequent type of brain cancer but has a poor prognosis. Currently, therapy for GBM relies primarily on surgery followed by radiotherapy and temozolomide [42]. Many genetic abnormalities linked with activation/ suppression of signal transduction pathways lead brain tumors to display a relative resistance to radiation therapy and other chemotherapeutic approaches [43]. Further, many GBMs and related malignancies exhibit mutations in epigenetic factors associated with histone methylation, including mutations in isocitrate dehydrogenase (which generates a novel metabolite that inhibits histone demethylases), histone H3.3 (which deregulates H3 methylation) [44] or SETD2 (which methylates H3K36) $[45,46]$. The widespread use of radiation therapy in GBM, and the importance of deregulated epigenetic control in GBM therefore provides a clinically relevant system for testing the use of inhibitors of methyltransferases as radiation sensitizers. We therefore screened a series of previously characterized histone methyltransferase inhibitors for their ability to sensitize GBM cell lines 
to ionizing radiation. In particular, we studied histone methylation at 4 sites (H3K9, H3K27, H3K79 and H4K20) known to be important for DSB repair. Overall, our results demonstrate that inhibition of histone methylation leads to significant sensitization of glioma cell lines to ionizing radiation, suggesting that combining radiation therapy with inhibitors of $\mathrm{H} 3 \mathrm{~K} 9$ methylation may be an important therapeutic strategy in human malignancies.

\section{RESULTS}

We identified 4 highly specific inhibitors of histone methyltransferases which function in DSB repair (Table 1). $\mathrm{H} 3 \mathrm{~K} 9 \mathrm{me} 3$ is increased at DSBs by SUV39H1 and related enzymes [15], where it functions to recruit repressors such as HP1 and activate DSB signaling [1]. However, SUV39H1 only produces H3K9me2 and H3K9me3, and requires prior monomethylation of $\mathrm{H} 3 \mathrm{~K} 9$ by the $\mathrm{G} 9 \mathrm{a}$ methyltransferase. BIX-01294 inhibits G9a [51], blocking formation of $\mathrm{H} 3 \mathrm{~K} 9 \mathrm{me} 1$ [52] and preventing subsequent conversion of $\mathrm{H} 3 \mathrm{~K} 9 \mathrm{me} 1$ to $\mathrm{H} 3 \mathrm{~K} 9 \mathrm{me} 2$ and $\mathrm{H} 3 \mathrm{~K} 9 \mathrm{me} 3$ by SUV39H1 (Table 1). BIX-01294 can therefore be used to probe the role of $\mathrm{H} 3 \mathrm{~K} 9$ methylation in genomic stability. Methylation of H3K27 by EZH2 [30, 32, 34] and H3K79 by DOT1L $[24,26]$ are also important for DSB repair. Inhibitors of DOT1L (Table 1: GSK126 - [41]) and EZH2 (Table 1: EPZ-5676 - [40]) have been used extensively in preclinical and clinical studies to target $\mathrm{H} 3 \mathrm{~K} 27$ and H3K79 methylation [38-41]. Finally, the 53BP1 DSB repair protein directly interacts with $\mathrm{H} 4 \mathrm{~K} 20 \mathrm{me} 2$ at DSBs $[9,53]$. H4K20 methylation requires initial monomethylation by SETD8, followed by methylation of H4K20me1 by the SUV420h family of methyltransferases to create H4K20me2 and H4K20me3 [54]. UNC0379 is a specific inhibitor of SETD8 which blocks the initial monomethylation of H4K20 and leads to genome wide loss of H4K20me1/2/3 [55]. UNC0379 can be used to probe the role of H4K20 methylation in DNA repair.

Loss of histone methylation can lead to altered transcription and disruption of the chromatin, and may potentially lead to cell death. Initially, we examined the toxicity of each inhibitor in MCF-7 cells. BIX-01294, EPZ-5676 and GSK126 showed minimal toxicity in MCF-7 cells at concentrations which inhibit their target enzymes, where as UNC0379, which targets SETD8, showed significant toxicity (Supplementary Figure 1A). For each of the 4 inhibitors, we then chose a concentration which caused $<25 \%$ lethality when either MCF-7 (Supplementary Figure 1A) or U343 GBM cells (Supplementary Figure 1B) were incubated in the drug for $24 \mathrm{hr}$. This concentration (Table 1) was used in all subsequent experiments. Next, we examined if individual histone methyltransferase inhibitors could sensitize MCF-7 breast cancer cells to ionizing radiation (Figure 1). Although methylation of histone H3K27 and $\mathrm{H} 3 \mathrm{~K} 79$ have been implicated in the repair of radiation- induced DNA damage [25, 26, 30, 32, 34], inhibition of either EZH2 (with GSK126; Figure 1A) or DOT1L (with EPZ-5676; Figure 1B) did not significantly alter the radiosensitivity of MCF-7 cells. Further, GSK126 and EPZ5676 did not alter radiosensitivity of other tumor cell lines, including the glioblastoma line U343 (Supplementary Figure 2A and 2B). Thus despite previous work implicating methylation of $\mathrm{H} 3 \mathrm{~K} 27$ and $\mathrm{H} 3 \mathrm{~K} 79$ in the damage response, inhibiting the enzymes which maintain these modifications does not significantly alter the overall sensitivity to ionizing radiation. In contrast, inhibition of either $\mathrm{H} 3 \mathrm{~K} 9$ methylation (with BIX-01294; Figure 1C) or H4K20 methylation (with UNC0379; Figure 1D) significantly increased the sensitivity of MCF-7 cells to ionizing radiation. Further, neither BIX-01294 or UNC0379 altered cell cycle progression at the concentrations used (Supplementary Figure 3). This indicates that changes in cell cycle position do not contribute to radiosensitization by either compound. Overall, Figure 1 demonstrates that loss of H3K9 or H4K20 methylation is associated with increased radiosensitivity, consistent with previous work demonstrating the importance of these modifications in DSB repair $[9,15]$.

The ability of UNC0379 to sensitize GBM cell lines to radiation was examined next (Figure 2). Cell survival curves were fitted to a linear quadratic model to aid in interpretation. The original data is available in Supplementary Dataset 1. LN382 and U87 cell lines showed no increase in radiation sensitivity with UNC0379 treatment (Figure 2A and $2 \mathrm{H}$ ), whereas the remaining cell lines displayed significant increases in radiosensitization (Figure 2B-2G). Western blot analysis confirmed that UNC0379 reduced H4K20me2 levels (Supplementary Figure 4C). To quantify this sensitization, we calculated the sensitizer enhancement ratio (SER) using 2 approaches (Figure 3A). The SER ${ }^{2 \mathrm{~Gy}}$ defines the fold increase in cell killing after inhibitor addition at $2 \mathrm{~Gy}$. In contrast, the $\mathrm{SER}^{50 \%}$ defines the ratio of doses required to achieve $50 \%$ survival in the presence and absence of inhibitor. Both values give largely the same SER (Figure 3A) for each cell line. U343 (Figure 2C) and U373 (Figure 2D) displayed the most robust increase in SER with UNC0379, whereas the remaining cells showed increases in SER of less than 1.3 (T98G, LN428, LN827, U118) or had no sensitization (LN382 and U87). Glioblastoma cell lines therefore display a range of sensitivities to UNC0379, suggesting differences in the contribution of H4K20 methylation to DNA repair in this panel of cells. We therefore examined if the levels of SETD8 (the target of UNC0379) or H4K20me2 correlated with radiosensitization by UNC0379 (Figure 3B). Cells displayed a wide range of SETD8 levels (Figure 3B), but there was no clear relationship between SETD8 protein levels and radio-sensitization. For example, U343 and LN428 cells had widely different levels of SETD8 (Figure 3B) yet both were sensitized to radiation 
Table 1: Specific inhibitors of $\mathrm{H3}$ methylation used in this study

\begin{tabular}{|c|c|c|c|c|c|}
\hline Methyltransferase & Methylation status & Inhibitor & IC50 & [ref] & DSB repair \\
\hline G9a & $\mathrm{H} 3 \mathrm{~K} 9 \rightarrow \mathrm{H} 3 \mathrm{~K} 9 \mathrm{me} 1$ & BIX-01294 & $1 \mu \mathrm{M}$ & {$[51]$} & $\begin{array}{l}\text { - HR repair } \\
\text { - Chromatin structure } \\
\text { - DNA damage signaling }\end{array}$ \\
\hline EZH2 & $\mathrm{H} 3 \mathrm{~K} 27 \rightarrow \mathrm{H} 3 \mathrm{~K} 27 \mathrm{me} 2 / 3$ & GSK126 & $5 \mu \mathrm{M}$ & {$[41]$} & $\begin{array}{l}\text { - Transcription } \\
\text { - DSB repair }\end{array}$ \\
\hline DOT1L & H3K79 $\rightarrow$ H3K79me3 & EPZ-5676 & $2.5 \mu \mathrm{M}$ & [40] & $\begin{array}{l}\text { - Genome stability/repair } \\
\text { - 53BP1 loading }\end{array}$ \\
\hline SETD8 & $\mathrm{H} 4 \mathrm{~K} 20 \rightarrow \mathrm{H} 4 \mathrm{~K} 20 \mathrm{me} 1$ & UNC0379 & $0.5 \mu \mathrm{M}$ & {$[55]$} & $\begin{array}{l}\text { - 53BP1 loading } \\
\text { - NHEJ repair } \\
\text { - Genome stability }\end{array}$ \\
\hline
\end{tabular}

G9a and SETD8 carry out only mono-methylation, while EZH2 and DOT1L can catalyze mono-, di- and tri-methylation.
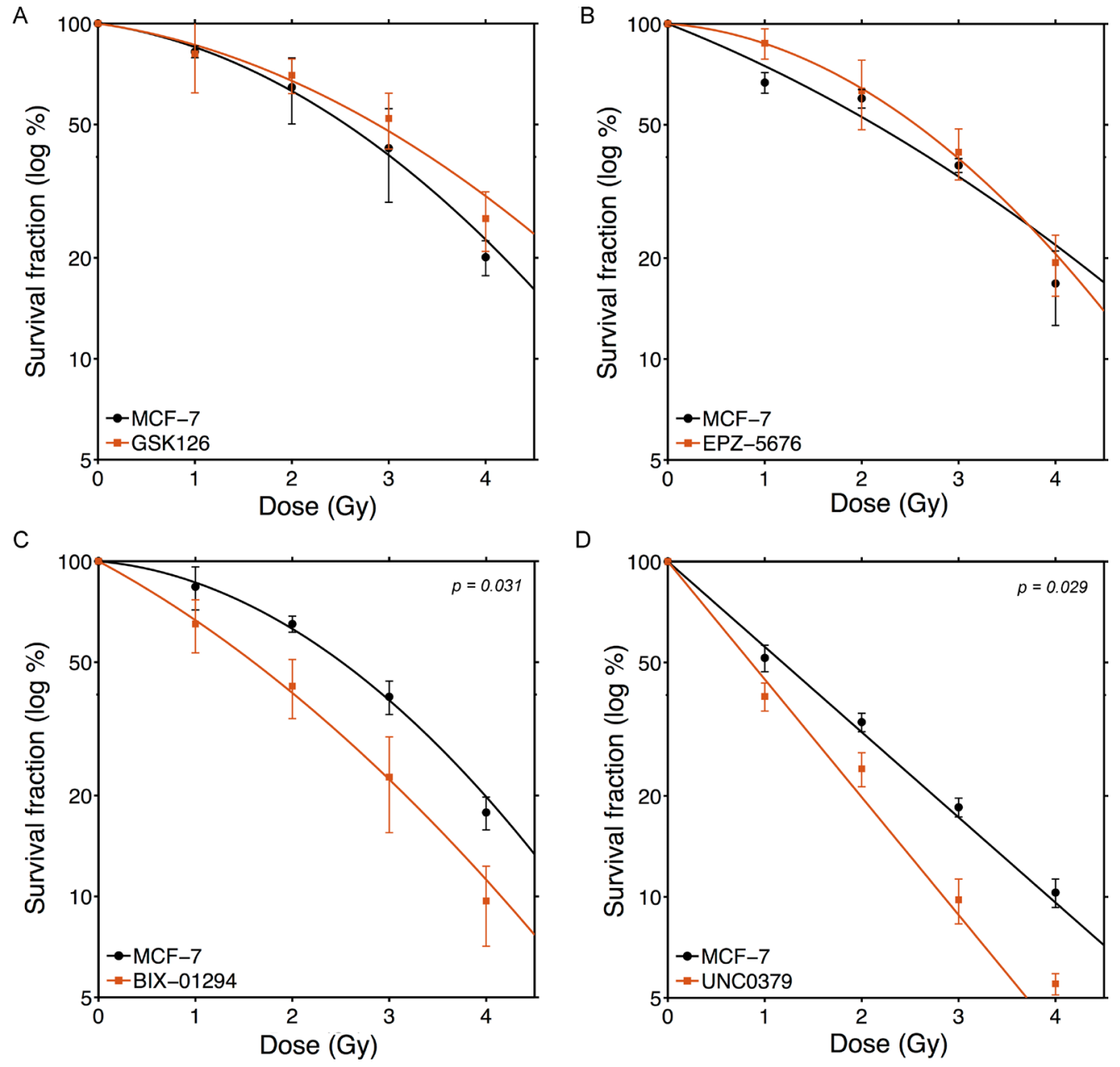

Figure 1: BIX-01294 and UNC0379 increase sensitivity of MCF-7 cells to ionizing radiation. MCF-7 cells were incubated with (A) GSK126 $(5 \mu \mathrm{M}),(\mathbf{B})$ EPZ-5676 $(2.5 \mu \mathrm{M}),(\mathbf{C})$ BIX-01294 $(1 \mu \mathrm{M})$ or (D) UNC0379 $(0.5 \mu \mathrm{M})$ for 4hr. Cells were then irradiated at the indicated dose. $20 \mathrm{hr}$ post-irradiation cells were washed to remove inhibitors, fresh media added and cells allowed to grow for 12 days. Surviving colonies were stained with crystal violet to assess clonogenic cell survival. Results + SD $(n=3$ biological replicates). Cell survival curves were fitted to a liner quadratic model. $P$-values for significant differences between slopes (calculated using the GraphPad Prism software package) shown where $p<0.05$. 
by SETD8 inhibition (Figure 2C and 2E). In addition, overall basal levels of H4K20me2 showed no direct link to either SETD8 (Figure 3B) or sensitization by UNC0379, suggesting that absolute levels of H4K20me2 are not related to overall radiation sensitivity. Finally, we examined how recruitment of 53BP1, which binds to damaged chromatin through dual interaction with both H4K20me2 and ubiquitinated H2A [7, 9], was affected by loss of H4K20me2. UNC0379 treatment did not alter phosphorylation of $\mathrm{H} 2 \mathrm{AX}$ when measured as either number of cells with $\gamma \mathrm{H} 2 \mathrm{AX}$ foci (Figure 3C) or number of $\gamma \mathrm{H} 2 \mathrm{AX}$ foci per cell (Supplementary Figure 4A). However, recruitment of 53BP1 to DSBs was reduced by UNC0379 (Figure 3C), consistent with a reduction in H4K20me2 seen with UNC0379 treatment. However, significant levels of 53BP1 were still detected at DSBs in the UNC0379 treated cells (Figure 3C), despite the large reduction in H4K20me2 (Supplementary Figure 4C). The loss of H4K20me2 is therefore not sufficient to fully block 53BP1 loading at DSBs. However, given that 53BP1 also binds to ubiquitinated $\mathrm{H} 2 \mathrm{~A}$, this residual 53BP1 binding may reflect interaction of 53BP1 with the ubiquitinated chromatin template.

Next, we screened the same panel of GBM cell lines with the G9a inhibitor BIX-01294 [51]. In contrast to the SETD8 inhibitor UNC0379, BIX-01294 sensitized all tested GBM cells to ionizing radiation (Figure 4; original data available in Supplementary Dataset 2). There was some variation in sensitivity, with T98G, LN428 and
LN827 showing lower levels of sensitization than the other 5 lines (Figure 4). Consistent with this increase in radiosensitivity after BIX-01294 treatment, all cell lines displayed increased $\mathrm{SER}^{2 \mathrm{~Gy}}$ and $\mathrm{SER}^{50 \%}$ values (Figure 5A) with the drug. However, the levels of the G9a methyltransferase (the target of BIX-0194) and H3K9me3 levels were broadly equivalent between cell lines (Figure 5B) and did not appear to predict the response to BIX-01294. For example, LN428 and LN827 had the lowest and highest levels of G9a respectively (Figure 5), but exhibited the same level of sensitization by BIX-0194. This indicates that inhibition of G9a by BIX-01294 can lead to broad increases in sensitivity to radiation in glioblastoma cell lines.

The increase in radiation sensitivity after BIX01294 treatment indicates that $\mathrm{H} 3 \mathrm{~K} 9 \mathrm{me} 2 / 3$ plays a key role in DSB repair. Previous work has shown that increased H3K9 can alter chromatin compaction at DSBs $[3,15,56]$ and plays a critical role in activating both the Tip60 acetyltransferase [17] and the ATM kinase $[20,57,58]$ after radiation. Tip60 binds directly to $\mathrm{H} 3 \mathrm{~K} 9 \mathrm{me} 2 / 3$ at DSBs, and this interaction increases Tip60's acetyltransferase and promotes acetylation of both histone $\mathrm{H} 4$ and the ATM kinase [17]. Further, treatment of cells with BIX-01294 reduces overall H3K9me3 levels (Supplementary Figure 4B). We therefore examined if inhibition of H3K9 methylation by BIX-01294 blocked activation of the Tip60 acetyltransferase after DNA damage. Tip60 acetylates histone $\mathrm{H} 4$ at DSBs [3],
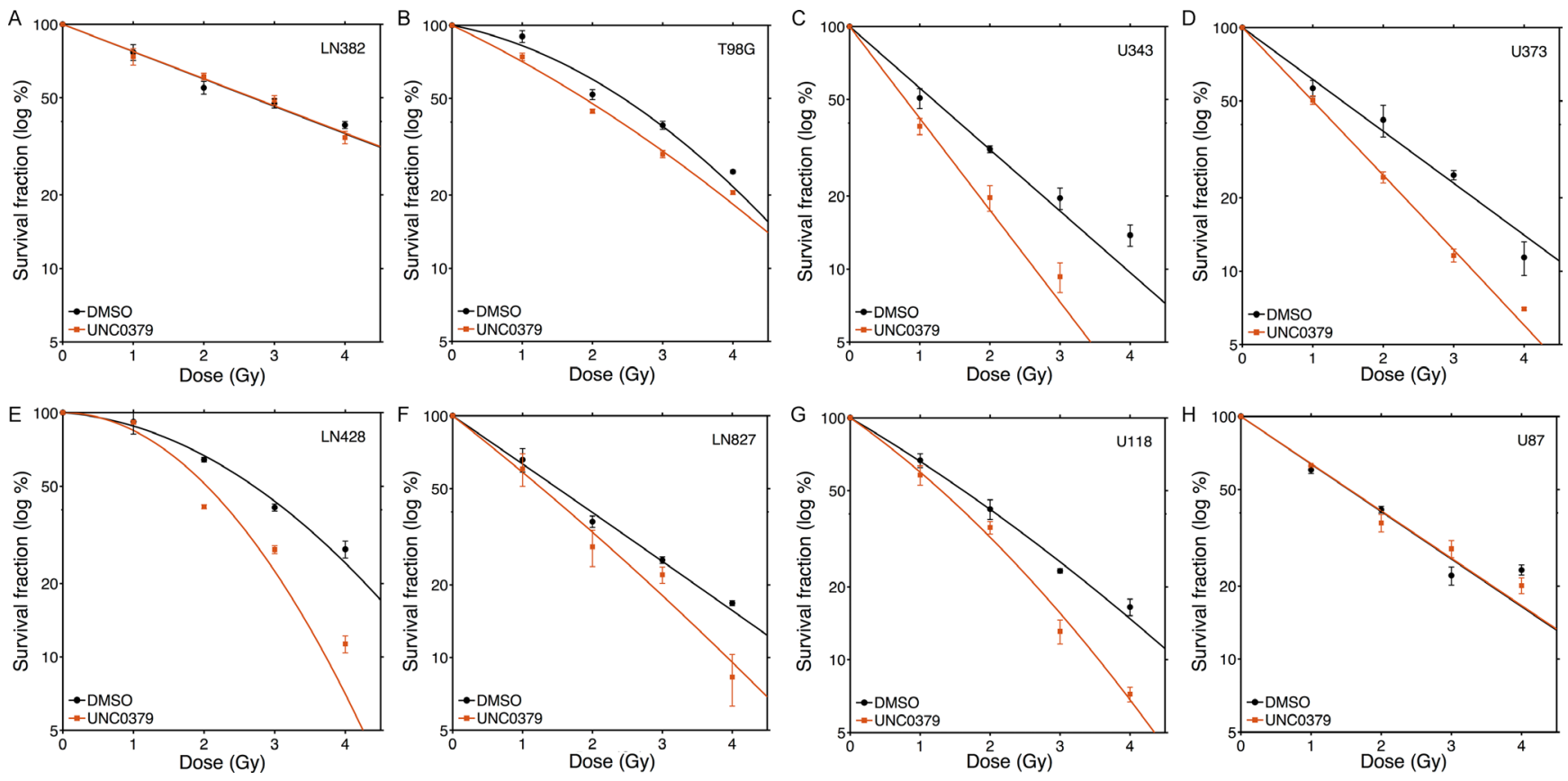

Figure 2: Increased radiosensitivity of glioblastoma cell lines following inhibition of SETD8 by UNC0379. Glioblastoma cell lines (A) LN382; (B) T98G; (C) U343; (D) U373; (E) LN428; (F) LN827; (G) U118 and (H) U87 were incubated in UNC0379 (0.5 $\mu$ M) for $4 \mathrm{hr}$. Cells were then irradiated at the indicated dose. $20 \mathrm{hr}$ post-irradiation cells were washed to remove inhibitor, fresh media added and cells allowed to grow for 12-15 days. Surviving colonies were stained with crystal violet to assess clonogenic cell survival. Results + SD ( $n=3$ biological replicates). Cell survival curves were fitted to a liner quadratic model. 
which promotes chromatin decondensation and DNA repair $[21,22]$. $\mathrm{H} 4$ acetylation $(\mathrm{H} 4 \mathrm{Ac})$ was measured by creating a sequence-specific DSB with the p84-Zinc Finger Nuclease (p84-ZFN), following by chromatin immunoprecipitation (ChIP) using a ChIP-grade H4Ac antibody. In DMSO treated cells, the p84-ZFN DSB increased H4Ac on the adjacent chromatin (Figure 6A). Further, when cells were incubated with BIX-01294 (to deplete H3K9 methylation; Supplementary Figure 4B), H4Ac was largely blocked (Figure 6A). This is consistent with Tip60 activation at DSBs requiring interaction with $\mathrm{H} 3 \mathrm{~K} 9 \mathrm{me} 2 / 3$ at adjacent DSBs. To further confirm this, we examined the ability of Tip60 to activate the ATM kinase. First, we used laser striping to create focused regions of DNA damage and monitored activation of ATM using an antibody which recognizes the phosphorylated, active form of ATM [59]. Immunofluorescent analysis using antibodies against $\gamma \mathrm{H} 2 \mathrm{AX}$ and pATM demonstrated increased phosphorylation of ATM and $\mathrm{H} 2 \mathrm{AX}$ in the region of DNA damage (Figure 6B). pATM levels were significantly reduced after addition of the ATM inhibitor KU55933, with both a reduction in signal intensity at each stripe as well as loss of pATM from the majority of the damaged region, despite the presence of significant amounts of $\gamma \mathrm{H} 2 \mathrm{AX}$. BIX-01294 also reduced the levels of pATM and the intensity of the $\gamma \mathrm{H} 2 \mathrm{AX}$ signal in the damaged region. In many cases, BIX-01294 cells retained $\gamma \mathrm{H} 2 \mathrm{AX}$ staining but lacked any detectable pATM signal (Figure 6B: arrows). This is consistent with BIX-01294 reducing $\mathrm{H} 3 \mathrm{~K} 9 \mathrm{me} 3$ levels and thereby inhibiting Tip60-
A

\begin{tabular}{lll} 
Cell line & SER $^{2 G y}$ & SER $^{50 \%}$ \\
\hline LN382 & 1.00 & 1.00 \\
T98G & 1.26 & 1.30 \\
U343 & 1.78 & 1.49 \\
U373 & 1.51 & 1.42 \\
LN428 & 1.30 & 1.33 \\
LN827 & 1.21 & 1.18 \\
U118 & 1.30 & 1.24 \\
U87 & 1.00 & 0.99
\end{tabular}

C

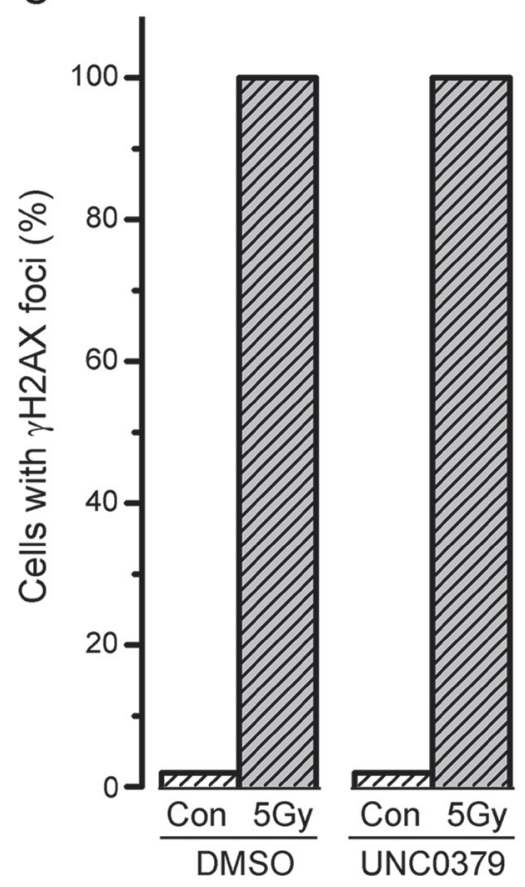

B

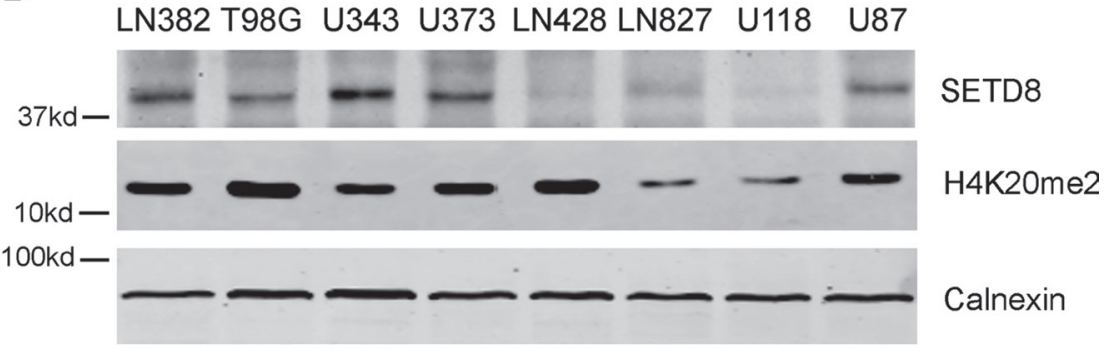

Figure 3: Levels of SETD8 and H4K20me2 do not correlate with radiosensitization by UNC0379. (A) SER ${ }^{2 \mathrm{~Gy}}$ (fold increase in cell kill at 2Gy with UNC0379) and SER ${ }^{50 \%}$ (fold decrease in dose required to kill 50\% cells in presence of UNC0379) data derived from figure 2. (B) Western blot analysis of SETD8, H4K20me2 and calnexin (loading control) in the indicated cell lines. (C) U2OS cells were incubated with DMSO (solvent) or UNC0379 $(0.5 \mu \mathrm{M})$ for $4 \mathrm{hr}$. Cells were then irradiated (5 Gy) and fixed 15 minutes later. Cells were processed for immunofluorescent staining using antibodies against $\gamma \mathrm{H} 2 \mathrm{AX}$ (left) and 53BP1 (right). Cells with $>10$ foci were counted, with a minimum of 100 cells counted. Results \pm SD $(n=4)$. $p$-value calculated using GraphPad Prism software package. 
dependent activation of the ATM kinase. To further confirm this reduction in ATM activity, we examined the ability of ATM to phosphorylate one of its key targets, the KAP-1 repressor protein [60]. Figure 6C demonstrates that ATM-dependent phosphorylation of KAP-1 was reduced following addition of BIX-01294. These results are consistent with BIX-01294 blocking accumulation of $\mathrm{H} 3 \mathrm{~K} 9 \mathrm{me} 2 / 3$ at DSBs, leading to failure to activate Tip60 and subsequent loss of Tip60-dependent acetylation of histone $\mathrm{H} 4$ and activation of ATM. Further, the reduction in ATM activation and loss of KAP-1 signal are similar to those reported following depletion of SUV39H1, which mediates $\mathrm{H} 3 \mathrm{~K} 9 \mathrm{me} 2 / 3$ production at DSBs [15]. The ability of BIX-01294 to sensitize cells to radiation may therefore reflect loss of Tip60 activity and failure to activate key Tip60-dependent pathways, including ATM, which are required for DSB repair.

Finally, we examined how BIX-01294 impacted the overall mechanism of DSB repair. There are 2 main pathways for DSB repair. In non-homologous end joining (NHEJ), the broken ends are processed and then directly religated. Alternatively, during S-phase, when sister chromatids are present, the damaged chromatid can use the adjacent sister chromatid as a template for repair by homologous recombination (HR). Using well defined reporters for NHEJ and HR $[49,50]$, we examined how BIX-01294 impacted the mechanism of DSB repair. BIX-01294 decreased HR, consistent with the known role of Tip60 in promoting HR
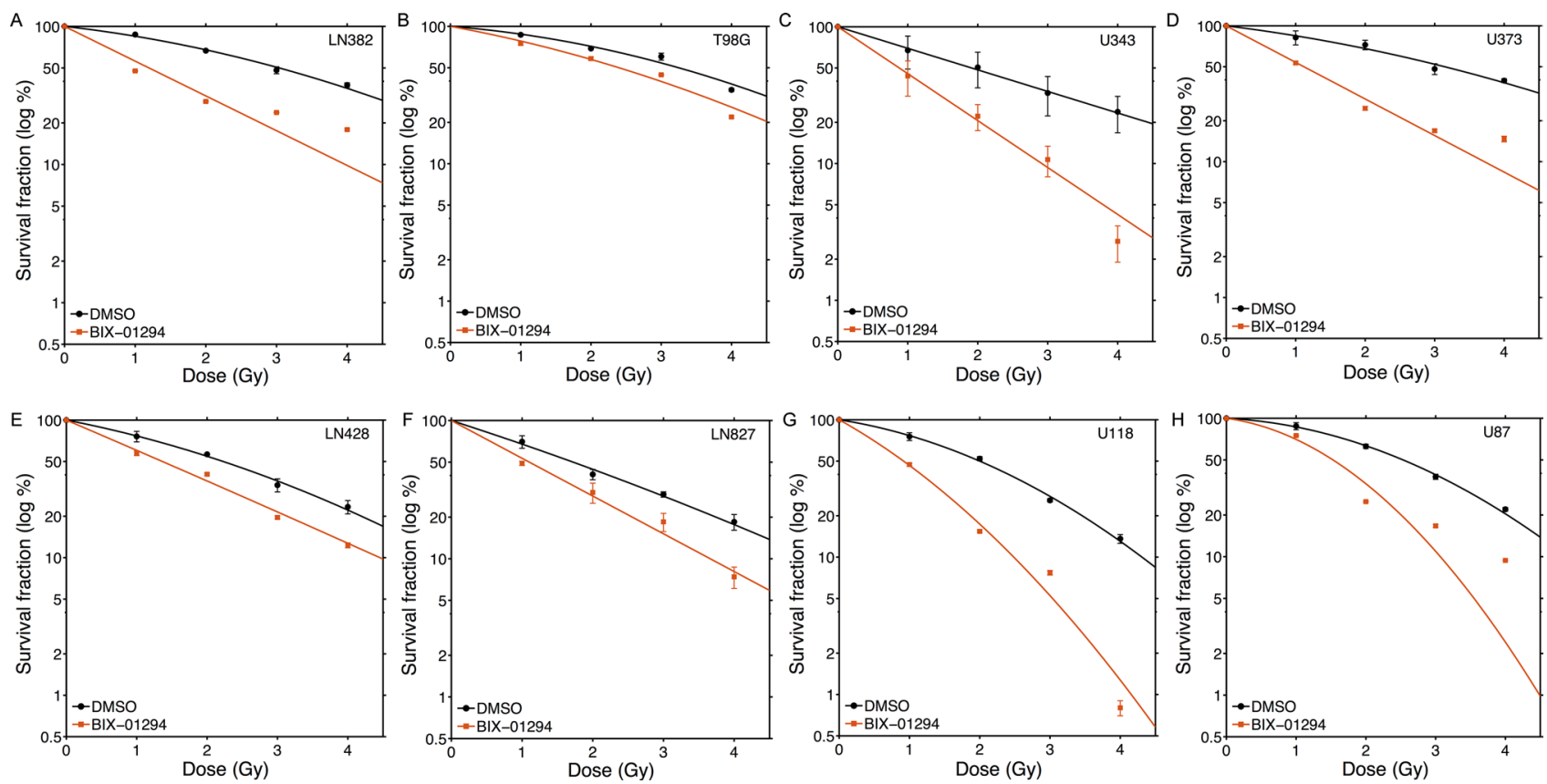

Figure 4: Increased radiosensitivity of glioblastoma cell lines following inhibition of G9a by BIX-01294. Glioblastoma cell lines (A) LN382; (B) T98G; (C) U343; (D) U373; (E) LN428; (F) LN827; (G) U118 and (H) U87 were incubated in BIX-01294 (1 $\mu$ M) for $4 \mathrm{hr}$. Cells were then irradiated at the indicated dose. $20 \mathrm{hr}$ post-irradiation cells were washed to remove inhibitor, fresh media added and cells allowed to grow for 12-15 days. Surviving colonies were stained with crystal violet to assess clonogenic cell survival. Results \pm $\mathrm{SD}(n=3$ biological replicates). Cell survival curves were fitted to a liner quadratic model.

A

\begin{tabular}{|c|c|c|}
\hline Cell line & SER $^{2 G y}$ & SER $50 \%$ \\
\hline LN382 & 2.15 & 2.54 \\
\hline T98G & 1.25 & 1.35 \\
\hline U343 & 2.35 & 2.18 \\
\hline U373 & 2.35 & 2.81 \\
\hline LN428 & 1.51 & 1.63 \\
\hline LN827 & 1.56 & 1.56 \\
\hline U118 & 2.87 & 2.18 \\
\hline U87 & 1.88 & 1.66 \\
\hline
\end{tabular}

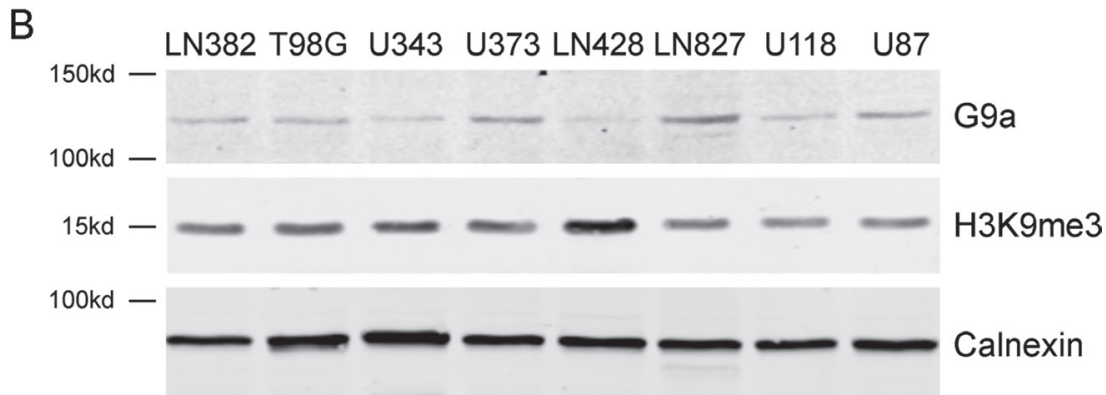

Figure 5: Levels of G9a and H3K9me3 do not correlate with radiosensitization by BIX-01294. (A) SER ${ }^{2 \mathrm{~Gy}}$ (fold increase in cell kill at 2Gy with UNC0379) and SER ${ }^{50 \%}$ (fold decrease in dose required to kill 50\% cells in presence of UNC0379) data derived from Figure 4. (B) Western blot analysis of G9a, H3K9me3 and calnexin (loading control) in the indicated cell lines. 
(Figure 7A). However, BIX-01294 also led to significant inhibition of NHEJ (Figure 7B). Loss of H3K9me2/3 therefore blocks DSB repair by both NHEJ and HR. This is consistent with previous studies indicating that increased $\mathrm{H} 3 \mathrm{~K} 9 \mathrm{me} 3$ at DSBs plays a key role in regulating local chromatin structure at DSBs, and that loss of $\mathrm{H} 3$ methylation can significantly disrupt early processing events at the break. Finally, BIX-01294 treated cells showed a delay in resolution of $\gamma \mathrm{H} 2 \mathrm{AX}$ foci after irradiation compared to untreated cells (Figure 7C). This indicates that that BIX-01294 treated cells have a defect in repair of DSBs and retain large numbers of unrepaired breaks compared to untreated cells.

\section{DISCUSSION}

These results demonstrate that targeted inhibition of histone methyltransferases which are critical for DNA repair can significantly increase tumor cell sensitivity to ionizing radiation. In particular, inhibition of G9a can disrupt H3K9 methylation and block DNA damage signaling, which leads to defective DNA repair and increased cell death. BIX-01294's ability to specifically inhibit G9a and block the initial methylation of H3K9 underscores the critical importance of precise $\mathrm{H} 3 \mathrm{~K} 9$ methylation in regulating both DSB signaling and DSB repair following exposure to ionizing radiation.
A

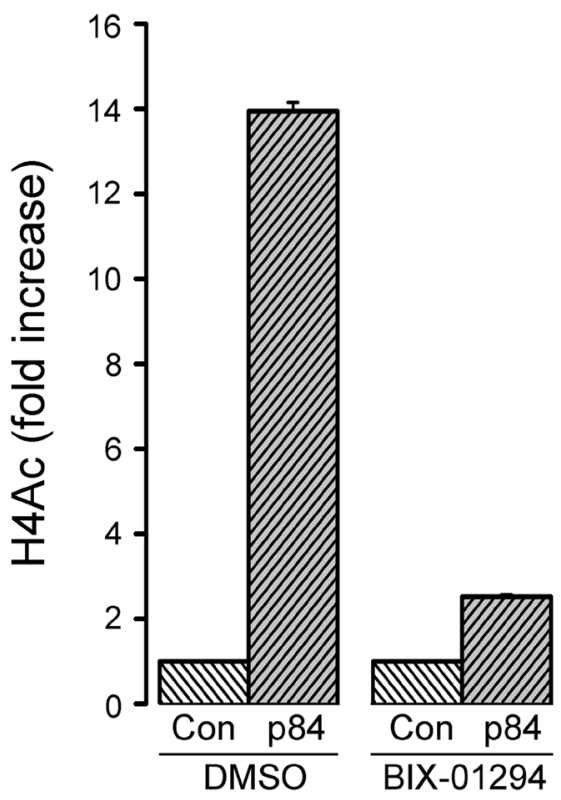

B

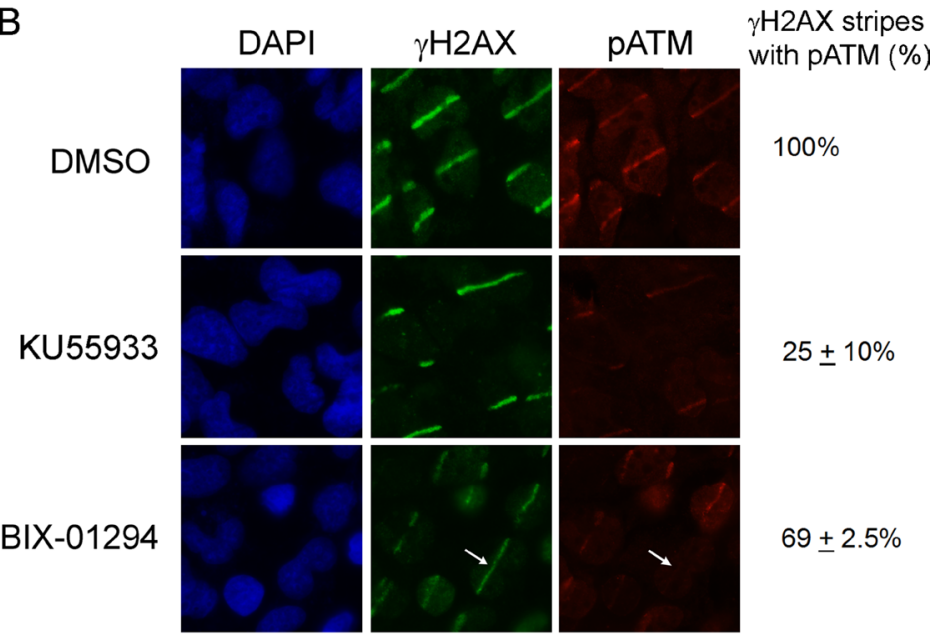

C

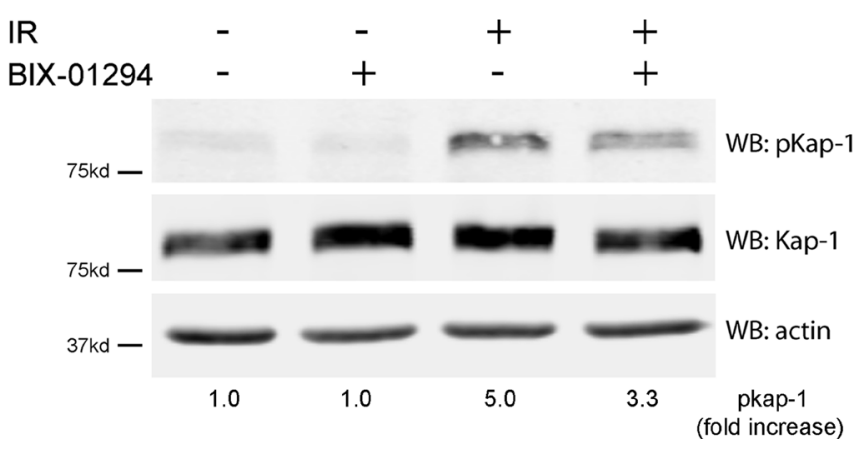

Figure 6: BIX-01294 blocks H3K9me3-dependent DNA damage signaling. (A) HEK293T cells were transfected with either empty vector (Con) or the p84-ZFN, followed by DMSO (solvent) or BIX-01294. 18hr later, cell extracts were prepared and processed for ChIP using antibodies to H4 and primers located 500bp from the DSB. (B) T98G cells were plated on coverslips and preincubated in either BIX-01294 $(1 \mu \mathrm{M})$ or the ATM inhibitor KU55933 $(10 \mu \mathrm{M})$. DNA damage was created using a low power laser striping system and cells allowed to recover for 30mins. Cells were then fixed and stained with DAPI or antibodies to $\gamma \mathrm{H} 2 \mathrm{AX}$ or pATM. Quantitation was performed by visual inspection of stripes, with any $\gamma \mathrm{H} 2 \mathrm{AX}$ stripe which had detectable pATM signal being counted as positive. This includes stripes which were clearly weaker than those in the control (DMSO) cells. $\gamma \mathrm{H} 2 \mathrm{AX}$ stripes lacking pATM indicated (arrow). (C) HEK293T cells were incubated with BIX-01294 $(1 \mu \mathrm{M})$ or solvent (DMSO) for $4 \mathrm{hr}$. Cells were then irradiated (10Gy) and allowed to recover for 30 mins. Cell extracts were the analyzed by western blot for phospho-KAP-1 (pKap-1), Kap-1 and actin (loading control). Fold increase in pKAP-1 signal (relative to unirradiated control) calculated using the Odyssey Software system 3.0 package and Li-Cor Odyssey Near Infra Red Imaging System (Li-Cor, NE). 
Inhibitors targeting 2 methyltransferases, DOT1L and $\mathrm{EZH} 2$, had no significant impact on overall survival following exposure to ionizing radiation. DOT1L is the only known H3K79 methyltransferase in cells and is important for chromatin organization, transcription and DNA repair [26, 61]. Previous work demonstrated that deletion of DOT1L did not increase radiation sensitivity [26], which is consistent with our observation that the DOT1L inhibitor EPZ-5676 did not alter radiation sensitivity. However, the role of DOT1L in DNA repair remains unclear, with some studies implicating DOT1L in recruiting 53BP1 to sites of damage [25], while others found no role for DOT1L in this [26]. Further, DOT1L and H3K79 methylation may play a broader role in maintaining genomic stability under different types of genotoxic stress. For example, DOT1L may be important for global genomic repair in yeast [24], and DOT1L inhibitors can sensitize MLL rearranged tumors to a range of chemotherapeutic agents [62]. DOT1L may therefore not be directly important for DSB repair, but may play a role in repair of other types of DNA lesion. Similar arguments apply to the role of EZH2 in DSB repair, where we observed that the EZH2 inhibitor GSK126 did not alter radiation sensitivity. This would seem at odds with a range of reports demonstrating that EZH2 and other components of the polycomb repressor complexes PRC1 and PRC2 are recruited to DSBs [28-32]. However, although increased $\mathrm{H} 3 \mathrm{~K} 27 \mathrm{me} 3$ at DSBs has been reported [30], several studies failed to note increased H3K27me 3 despite the presence of EZH2 at the break site [28, 31, 32]. This may indicate that the catalytic activity of EZH2 is not important for its DNA repair functions. Instead, because EZH2 is recruited to DSBs as part of the larger PRC2 complex, other sub-units of the complex may be important for DNA repair. Further, components of PRC1 and PRC2 may be important for transcriptional silencing and repair within transcribed regions [28], rather than genome wide repair of DSBs. EZH2 and the PRC2 complex may therefore only be crucial for repair of a sub-set of DSBs within the cell. Such a conclusion would be consistent with the inability of EZH2 inhibitors to alter overall sensitivity to ionizing radiation.

53BP1 is recruited to DSBs through dual interaction with ubiquitinated $\mathrm{H} 2 \mathrm{~A}$ and $\mathrm{H} 4 \mathrm{~K} 20 \mathrm{me} 2$ [7, 9]. More than $80 \%$ of $\mathrm{H} 4$ is basally methylated in mammalian cells [13]. SETD8 (PR-Set7/KMT5A) is the only known H4K20 mono-methylase, creating H4K20me1, which can then be subsequently converted to $\mathrm{H} 4 \mathrm{~K} 20 \mathrm{me} 2 / 3$ by the SUV4-20H1 and SUV4-20H2 methyltransferases [61]. Further, loss of either SETD8 [12, 63] or SUV4-20H1/ $\mathrm{H} 2$ [14] leads to decreased retention of 53BP1 at DSBs and increased sensitivity to DNA damage. Our results are broadly in line with studies targeting H4K20 methylation $[7,64]$, with inhibition of SETD8 by UNC0379 leading to chromatin-wide loss of $\mathrm{H} 4 \mathrm{~K} 20 \mathrm{me} 2$, reduced 53BP1 loading and increases in radiosensitivity. However, inhibition of SETD8 by UNC0379 was less effective at blocking 53BP1 loading than previous experiments which targeted SETD8 with siRNA [12, 63]. These workers noted that SETD8 was recruited to DSBs where it directly methylated H4K20 and promoted 53BP1 loading. It is possible that UNC0379 does not completely block the
A

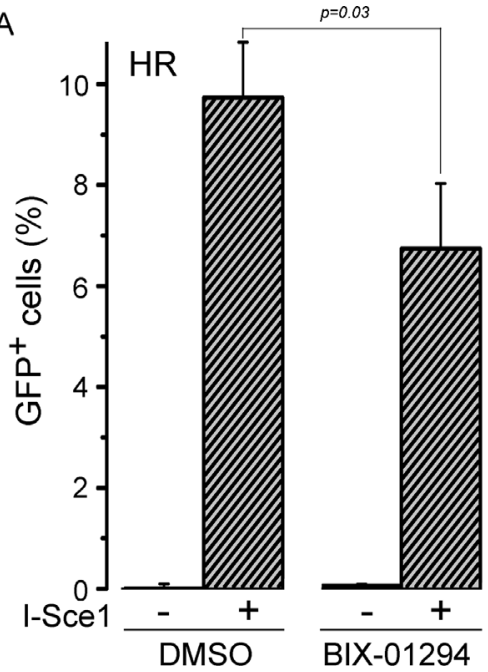

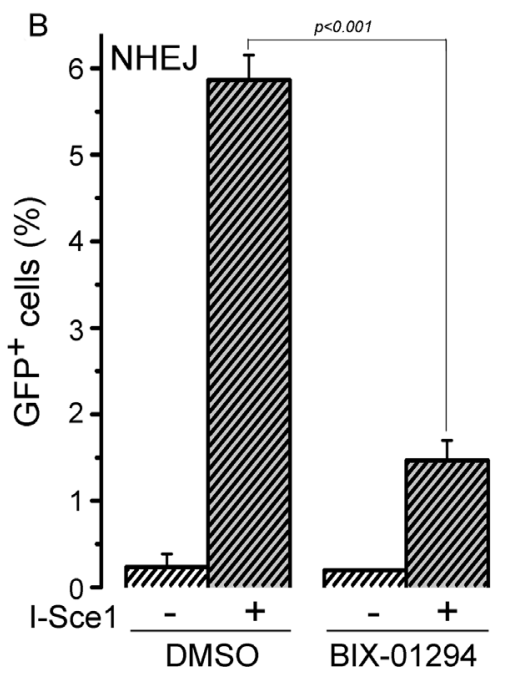

Figure 7: BIX-01294 blocks HR and NHEJ mediated DNA repair. (A) U2OS cells with a stably integrated EJ-GFP HR reporter were transfected with either empty vector $(-)$ or I-Sce1 $(+)$ followed by DMSO (solvent) or BIX-01294. Cells were allowed to grow for 2 days and then analyzed by FACS to identify GFP positive cells. Results $\pm \mathrm{SD}(n=3)$. $p$-value calculated using GraphPad Prism software package. (B) HeLa cells with a stably integrated NHEJ reporter were transfected with either empty vector (-) or I-Sce1 (+) followed by DMSO (solvent) or BIX-01294. Cells were allowed to grow for 2 days and then analyzed by FACS to identify GFP positive cells. Results \pm $\mathrm{SD}(n=3)$. $p$-value calculated using GraphPad Prism software package. (C) U2OS cells were incubated with DMSO (o) or BIX-01294 (·) for $4 \mathrm{hr}$. Cells were then irradiated (5Gy) and fixed. Cells were processed for immunofluorescent staining using antibodies against $\gamma \mathrm{H} 2 \mathrm{AX}$. Cells with $>10$ foci were counted, with a minimum of 100 cells counted. Results $\pm \operatorname{SD}(n=4)$ 
ability of SETD8 to methylate H4K20, so that residual H4K20me1 can still accumulate at DSBs and facilitate loading of 53BP1. Further, the MMSET methyltransferase has also been suggested to be recruited to DSBs [65], where it methylates H4K20 and promotes 53BP1 loading. This suggests that MMSET may provide a route for increasing H4K20me2 levels when SETD8 is inhibited by UNC0379. However, because in vitro studies indicate that MMSET does not methylate H4K20 [13, 66], further work is needed to evaluate the role of MMSET in H4K20 methylation at DSBs. Finally, because 53BP1 binding at DSBs requires interaction with both H4K20me2 and ubiquitinated $\mathrm{H} 2 \mathrm{~A}$ [9], a reduction in $\mathrm{H} 4 \mathrm{~K} 20 \mathrm{me} 2$ levels may be partly compensated for by the continued binding of 53BP1 to ubiquitinated H2A. Further, given the complexity of 53BP1 binding and regulation at DSBs, it is not surprising that reducing H4K20me2 only has a limited impact on both 53BP1 recruitment and radiosensitivity.

Inhibition of the G9a methyltransferase by BIX01294 sensitized all tested cell lines to radiation, underscoring the critical importance of $\mathrm{H} 3 \mathrm{~K} 9$ methylation in DNA repair [11]. G9a functions primarily to create $\mathrm{H} 3 \mathrm{~K} 9 \mathrm{me} 1$ and is required for subsequent creation of H3K9me2 and H3K9me3 by SUV39H1 and related methyltransferases. Previous work has demonstrated that H3K9 methylation can play a role both directly at DNA breaks as well as being important for maintaining overall genomic integrity $[3,15,17]$. Several studies indicate that increased $\mathrm{H} 3 \mathrm{~K} 9 \mathrm{me} 2 / 3$ at DSBs leads to accumulation of many repressor proteins, including HP1 and KAP-1 [15, $18,19,67]$, on the chromatin at breaks. These repressors modulate chromatin organization and accessibility and can directly facilitate DSB repair $[2,15,16]$. Increased H3K9me2/3 can also directly activate the Tip60 acetyltransferase [17], which in turn acetylates both histone $\mathrm{H} 4[21,22,68]$ and the ATM kinase $[17,20]$. Increased $\mathrm{H} 3 \mathrm{~K} 9 \mathrm{me} 2 / 3$ at DSBs is therefore a critical step in regulating both chromatin organization and signaling in response to DNA breaks. Further, because H3K9me2/3 plays a critical role in organizing heterochromatin structures, loss of H3K9 (and related binding proteins) can lead to destabilization of heterochromatin with an increase in spontaneous damage [69]. It is also clear that DSB repair in heterochromatin utilizes a distinct mechanism which requires precise remodeling of the repressed chromatin through phosphorylation of KAP$1[60,70,71]$ and recruitment of remodeling complexes [72], which function together to create more open, repair proficient chromatin domains [73]. Our data clearly shows that inhibition of G9a blocks much of the H3K9me2/3 driven signaling, including blocking activation of the ATM kinase and Tip60 acetyltransferases, with consequent loss of both $\mathrm{H} 4$ acetylation and phosphorylation of KAP-1. Interestingly, studies by Bakkenist et al showed that chromatin decompaction in the absence of DNA damage can activate ATM [59]. Because BIX-01294 decreases $\mathrm{H} 3 \mathrm{~K} 9 \mathrm{me} 2 / 3$ and promotes chromatin decompaction, it might be expected that BIX-01294 should activate ATM. However, we suggest that the methods used in [59] to promote chromatin decompaction may expose previously buried $\mathrm{H} 3 \mathrm{~K} 9 \mathrm{me} 3$, which leads to general activation of Tip60 and ATM's kinase activity. Because BIX-01294 decreases H3K9 methylation, it will still block Tip60 and ATM activation even though the chromatin is in a more open conformation. The ability of BIX-01294 to increase radiosensitivity therefore derives from inhibition of DSB repair signaling pathways which are dependent on increased H3K9 methylation. Inhibition of G9a therefore represents a powerful target for development of novel radiosensitizers.

G9a is amplified in several cancers, including ovarian, head and neck, brain and other solid tumors [74-77]. Targeting G9a with inhibitors in these tumors, in combination with standard chemo or radiotherapy, may provide a new approach for treating these diseases. Although we did not find a strong correlation between G9a expression levels and sensitization by BIX-0192 in our small panel of glioma cell lines, it remains to be seen whether G9a overexpression in other tumors may be exploited to increase sensitivity to radiation therapy or chemotherapy.

This work clearly demonstrates that histone methylation pathways such as H3K9 methylation (or H4K20) which are required for DNA repair are novel targets for the development of radiosensitizers with therapeutic relevance. In particular, inhibition of G9a and loss of H3K9 methylation is highly effective at sensitizing cells to ionizing radiation, and potentially to other types of DNA damaging agents. Many tumors exhibit deregulation of histone modifications stemming from changes in e.g. histone methyltransferases or histone demethylases, leading to an altered epigenetic landscape. The ability to erase these changes through the directed use of epigenetic inhibitors provides the opportunity to correct epigenetic defects. While much work has focused on how the altered epigenetic landscape in tumors can impact transcription, our results underline the need to consider the impact of these epigenetic changes on DNA repair, oncogene induced senescence [71] and chromatin architecture in tumor cells. As new epigenetic inhibitors are synthesized and tested in preclinical and clinical settings, it will be important to consider combining them with radiation or other types of DNA-damaging chemotherapy.

\section{MATERIALS AND METHODS}

\section{Cells, cell survival and irradiation}

U2OS, HEK293T, HeLa cells, U87, U118, T98G and MCF-7 (American Type Culture Collection, VA) 
and U343, U373, LN428, LN827, LN382 [47] were maintained in Dulbecco's Modified Eagles Medium supplemented with 10\% Fetal Bovine Sera. Cells were tested monthly for mycoplasma, and routinely replenished after less than 20 passages in culture from central stocks. For clonogenic cell survival assays, cells were plated in triplicate at an appropriate dilution on 6-well dishes and allowed to attach for $24 \mathrm{hr}$. Cells were irradiated using a $\mathrm{Cs}^{137}$ irradiator and allowed to recover for 10-14 days. Cells were then fixed and stained with $10 \%$ ethanol containing $2.5 \%(\mathrm{w} / \mathrm{v})$ crystal violet and colonies with $>$ 50 cells scored visually as previously described [48]. All cell survival experiments consisted of at least 3 biological replicates, with data analyzed to calculate averages and standard deviation. Cell cycle analysis was carried out as described in [3].

\section{Data analysis and curve fitting}

For each cell survival, cells were irradiated to a total dose of 1Gy, 2Gy, 3Gy or 4 Gy in the presence of dimethyl sulfoxide (DMSO) or inhibitor. Experimental data representing survival fractions $(\mathrm{S})$ for each cell line were fitted to the linear-quadratic (LQ) model. In the LQ model, the cell can be killed through a single lethal event or two (or more) sub-lethal events. LQ is mathematically described with the following formula:

$$
S=e^{-\left(a \cdot D+\beta \cdot D^{2}\right)}
$$

where $\mathrm{D}$ is the dose in Gray (Gy), $\alpha$ is a proportionality constant that describes the linear component of the LQ curve and relates cell survival with single radiation events. $\beta$ is a proportionality constant that describes the quadratic component of the LQ curve and relates cell survival with two radiation events. Sensitization enhancement ratio (SER) is a measure of the enhancement of cell response to irradiation. $S E R_{2 G y}$ indicates the enhancement in cell death at the dose of $2 \mathrm{~Gy}$ in the presence of the radiosensitizer. It is calculated by:

$$
S E R_{2 G y}=\frac{S^{D M S O}}{S^{i n h}}
$$

where $S^{D M S O}$ is the surviving fraction $2 \mathrm{~Gy}$ at in the presence of DMSO and $S^{\text {inh }}$ is the survival fraction at the same dose in the presence of inhibitor. The dose of $2 \mathrm{~Gy}$ is commonly used in clinical exposures. $S E R_{50 \%}$ indicates the dose required to achieve the same effect (i.e. $50 \%$ survival) in the presence of the radiosensitizer. It is calculated by:

$$
S E R_{50 \%}=\frac{D^{D M S O}}{D^{\text {inh }}}
$$

where $D^{D M S O}$ is the dose required for $50 \%$ survival in the presence of DMSO and $D^{i n h}$ is the dose required for the same survival fraction in the presence of UNC0379 or BIX-01294 inhibitor.

\section{Laser striping and microscopy}

T98G cells were plated at a density of $10^{5}$ cells per well on 12 well plates containing round, $18 \mathrm{~mm}$ coverslips. $24 \mathrm{hr}$ later, cells were treated with either $1 \mu \mathrm{M}$ BIX-01294 or $10 \mu \mathrm{M}$ KU55933. Laser stripes were created using the Zeiss PALM MicroBeam $(\lambda=355 \mathrm{~nm}$, $\mathrm{E}<60 \mathrm{uJ}, \mathrm{f}=100 \mathrm{~Hz}, \mathrm{t}<2 \mathrm{~ns})$, using the $63 \mathrm{x}$ objective and with the laser output set to $28 \%$. Cells were allowed to recover for 30 minutes after micro-irradiation, fixed with paraformoldehyde 4\% (15 minutes), permeabilized with $0.5 \%$ Triton X-100 (15 minutes) and blocked with $5 \%$ BSA (1hr). Slides were then incubated overnight with anti-pATM antibody (Rockland, PA: 200-301-400 - 1:250 dilution) and anti- $\gamma \mathrm{H} 2 \mathrm{AX}$ (Cell Signaling, MA: 2577S - 1: 80 dilution), followed by secondary antibodies (Invitrogen, CA: A21203 and A11034 - 1:500 dilution) for 1 hour. Antibodies were diluted in a 3\% BSA with $0.1 \%$ Triton solution. The images were acquired with $63 \times$ magnification.

\section{Monitoring 53BP1 foci}

For 53BP1 foci, U2OS cells were plated as above on cover slips and irradiated (10Gy). Cells were allowed to recover for $15 \mathrm{~min}$, then fixed with $\mathrm{PBS} /$ paraformaldehyde $(4 \%)$, permeabilized and incubated in Triton X-100 $(0.2 \%)$ for 5 minutes. Cells were then washed twice in PBS and blocked with fetal bovine serum (10\%/20 mins). Slides were incubated with primary antibody to either 53BP1 (Abcam, MA - 21083) or $\gamma \mathrm{H} 2 \mathrm{AX}$ (Cell Signaling, MA - 2577S) and secondary antibody with washing between each step. Slides were mounted with Fluoromount-G (Southern Biotech, AL) and imaged with a Zeiss AxioImager Z1 microscope equipped with an Axiocam MRc Rev.3 Color Digital Camera and Plan APO 63X/1.4 oil M27 lens (magnification 63X, aperture 1.4). Acquisition software and image processing utilized the Zeiss AxioVision software package (Zeiss Imaging, NY). Cells with $>10$ foci were then counted.

\section{Western blot}

Whole cell extracts were prepared by incubating cells in RIPA buffer (50 mM Tris pH7.5, $150 \mathrm{mM}$ $\mathrm{NaCl}, 1 \mathrm{mM}$ EDTA, $0.1 \%$ SDS, 1\% NP-40, 1\% sodium deoxycholate) with protease inhibitor cocktail (Roche, IN) for 1 hour at $4^{\circ} \mathrm{C}$. Protein concentration was measured using the Bio-Rad DC Protein assay kit (Bio-Rad, CA). For western blots, proteins were separated by SDS-PAGE and transferred to nitrocellulose membranes. Membranes were blocked with $5 \%$ milk, incubated with antibodies against G9a (R\&D Systems: PP-A8620A-00), SETD8 (Abcam, MA: \#ab3798), KAP-1 (Bethyl Labs, PA: A300274A), pKAP-1 (Bethyl Labs: A300-767A), actin (Santa 
Cruz, CA: sc-47778) or Calnexin (Sigma, MI: \#C4731) for 1 hour, washed in TBS-T (20 mM Tris $\mathrm{pH} 7.5$, $137 \mathrm{mM} \mathrm{NaCl}, 0.1 \%$ Tween 20 ), and then incubated with goat anti-mouse IR Dye-800CW or goat anti-rabbit IR Dye-680CW conjugated secondary antibodies (Li-Cor Inc, $\mathrm{NE}$ ). Imaging was carried out using the Li-Cor Odyssey Near Infra Red System, and analyzed using the Odyssey Software system 3.0 package (Li-Cor, NE). Histones were extracted using the Histone Extraction Kit (Abcam, MA: ab113476) and antibodies to H4K20me2 (Abcam, MA: \# ab9052) and H3K9me3 (Abcam, MA: ab8898) were used for western blot analysis as described above.

\section{ChIP assays}

HEK293T cells were transfected with p84-ZFN to create a specific DSB in the PPP1R12C gene. 18hr later, cells were fixed ( $1 \%$ methanol-free formaldehyde $/ 10 \mathrm{~min}$ ) to crosslink DNA and proteins, then lysed in Chromatin Immunoprecipitation (ChIP) buffer using kits (Cell Signaling Technology, MA, USA: \#9005). Samples were then sonicated and cleared by centrifugation. Part of the supernatant was digested with proteinase $\mathrm{K}\left(65^{\circ} \mathrm{C}\right.$ for $2 \mathrm{hr}$ ), the DNA isolated by spin columns and input DNA quantitated by Real Time PCR (using primers against 18S rRNA genomic sequence). For ChIP, equivalent amounts of chromatin were incubated with H4Ac antibody (Millipore, CA: 06-866) overnight at $4^{\circ} \mathrm{C}$, followed by protein $\mathrm{G}$ agarose beads precoated with sperm DNA. Immune complexes were washed in low and high salt ChIP buffers (Cell Signaling Technology, MA - \#9005), eluted, incubated in $\mathrm{NaCl}\left(65^{\circ} \mathrm{C}\right.$ for $\left.2 \mathrm{hrs}\right)$ and then digested with proteinase K. Purified DNA was quantitated by RT-qPCR using the Step One Plus real time PCR system (Applied Biosystems, CA). PCR protocols and primer pairs are listed below.

\section{Real-Time quantitative PCR and data analysis}

The level of DSB production by p84-ZFN was monitored using PCR, as we previously described [21]. Genomic DNA (prepared as above) was amplified using primer pairs located either side of the DSB (listed below) by real time qPCR and the percent of DSBs estimated by the change in signal resulting from cleavage of the DNA. 18s rRNA genomic DNA signal was used to ensure equal input DNA.

PCR amplification (using the Step One Plus real time PCR system fromApplied Biosystems, CA) utilized an initial step of $95^{\circ} \mathrm{C}$ for 5 mins and 33 cycles of: 30sec @ 95 ${ }^{\circ} \mathrm{C} / 30 \mathrm{sec} @ 60^{\circ} \mathrm{C} / 30 \mathrm{sec} @ 72^{\circ} \mathrm{C}$ and a final extension step of 5mins@72 9 C. Serial dilutions of the starting material were used to determine the linear range of PCR amplification prior to use. 18S rRNA genomic sequences were used to standardize input genomic DNA. Standard controls included immunoprecipitation with $\mathrm{IgG}$, which yielded essentially no signal. Relative fold enrichment were optimized to the input control and expressed as IP/
Input DNA. The relative increase in signal after cutting by $\mathrm{p} 84-\mathrm{ZFN}$ was calculated as $\left[\mathrm{IP}^{\mathrm{ZFN}} /\right.$ Input $\left.^{\mathrm{ZFN}}\right] /\left[\mathrm{IP}^{\mathrm{Control} /}\right.$

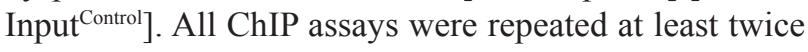
(biological replicates), with individual RT-qPCR reactions carried out in duplicate (technical replicate) and the results presented \pm standard deviation.

Primers $0.5 \mathrm{~kb}$ from DSB: (ATGGTGCGTCC TAGGTGTTC and CCAAGGACTCAAACCCAGAA); Primers for DSB efficiency: (CGGTTAATGTGGCTCTGG TT and ACAGGAGGTGGGGGTTAGAC); Primers to $18 \mathrm{~S}$ rRNA DNA: (CCCAGTAAGTGCGGGTCATA and GATCCGAGGGCCTCACTAAAC).

\section{HR/NHEJ assay}

DNA repair assays utilized U2OS cells expressing the DR-GFP HR reporter [49] or HeLa cells expressing an NHEJ reporter [50]. Cells were treated with DMSO or BIX-01294. $24 \mathrm{hr}$ later, cells were transfected with I-Sce I or eGFP (control) plasmid using Lipofectamine 2000 (Invitrogen, CA). 48 hr later GFP positive cells were analyzed using the BD LSR II cell analyzer (BD Biosciences, CA) and data analyzed with the BD Diva software package. Data were normalized according to eGFP (control) transfected cells to correct for transfection efficiency.

\section{CONFLICTS OF INTEREST}

The authors declare that they have no conflicts of interest to disclose.

\section{FUNDING}

This work was funded by NIH grants CA64585, CA93602 and CA177884 to BDP.

\section{Authors' contributions}

OG-Y and BDP conceived the study and wrote the paper; RBS and VV carried out laser striping and immunofluorescent studies; OG-Y and CC carried out experiments; OG-Y and MM analyzed data and carried out statistical analysis.

\section{REFERENCES}

1. Gursoy-Yuzugullu O, House N, Price BD. Patching Broken DNA: Nucleosome Dynamics and the Repair of DNA Breaks. J Mol Biol. 2016; 428:1846-60.

2. Smeenk G, van Attikum $H$. The chromatin response to DNA breaks: leaving a mark on genome integrity. Annu Rev Biochem. 2013; 82:55-80.

3. Gursoy-Yuzugullu O, Ayrapetov MK, Price BD. Histone chaperone Anp32e removes H2A.Z from DNA double-strand 
breaks and promotes nucleosome reorganization and DNA repair. Proc Natl Acad Sci USA. 2015; 112:7507-7512.

4. Rogakou EP, Boon C, Redon C, Bonner WM. Megabase chromatin domains involved in DNA double-strand breaks in vivo. J Cell Biol. 1999; 146:905-916.

5. Shiloh Y, Ziv Y. The ATM protein kinase: regulating the cellular response to genotoxic stress, and more. Nat Rev Mol Cell Biol. 2013; 14:197-210.

6. Jackson SP, Durocher D. Regulation of DNA damage responses by ubiquitin and SUMO. Mol Cell. 2013; 49:795-807.

7. Fradet-Turcotte A, Canny MD, Escribano-Diaz C, Orthwein A, Leung CC, Huang H, Landry MC, KitevskiLeBlanc J, Noordermeer SM, Sicheri F, Durocher D. 53BP1 is a reader of the DNA-damage-induced H2A Lys 15 ubiquitin mark. Nature. 2013; 499:50-54.

8. Mattiroli F, Vissers JH, van Dijk WJ, Ikpa P, Citterio E, Vermeulen W, Marteijn JA, Sixma TK. RNF168 ubiquitinates $\mathrm{K} 13-15$ on $\mathrm{H} 2 \mathrm{~A} / \mathrm{H} 2 \mathrm{AX}$ to drive DNA damage signaling. Cell. 2012; 150:1182-1195.

9. Panier S, Boulton SJ. Double-strand break repair: 53BP1 comes into focus. Nat Rev Mol Cell Biol. 2014; 15:7-18.

10. Bunting SF, Callen E, Wong N, Chen HT, Polato F, Gunn A, Bothmer A, Feldhahn N, Fernandez-Capetillo O, Cao L, Xu X, Deng CX, Finkel T, et al. 53BP1 inhibits homologous recombination in Brcal-deficient cells by blocking resection of DNA breaks. Cell. 2010; 141:243-254.

11. Price BD, D'Andrea AD. Chromatin remodeling at DNA double-strand breaks. Cell. 2013; 152:1344-1354.

12. Tuzon CT, Spektor T, Kong X, Congdon LM, Wu S, Schotta G, Yokomori K, Rice JC. Concerted activities of distinct H4K20 methyltransferases at DNA double-strand breaks regulate 53BP1 nucleation and NHEJ-directed repair. Cell Rep. 2014; 8:430-438.

13. van Nuland R, Gozani O. Histone H4 Lysine 20 (H4K20) Methylation, Expanding the Signaling Potential of the Proteome One Methyl Moiety at a Time. Molecular \& cellular proteomics. 2016; 15:755-764.

14. Schotta G, Sengupta R, Kubicek S, Malin S, Kauer M, Callen E, Celeste A, Pagani M, Opravil S, De La RosaVelazquez IA, Espejo A, Bedford MT, Nussenzweig A, et al. A chromatin-wide transition to H4K20 monomethylation impairs genome integrity and programmed DNA rearrangements in the mouse. Genes \& development. 2008; 22:2048-2061.

15. Ayrapetov MK, Gursoy-Yuzugullu O, Xu C, Xu Y, Price BD. DNA double-strand breaks promote methylation of histone $\mathrm{H} 3$ on lysine 9 and transient formation of repressive chromatin. Proc Natl Acad Sci USA. 2014; 111:9169-9174.

16. Khurana S, Kruhlak MJ, Kim J, Tran AD, Liu J, Nyswaner K, Shi L, Jailwala P, Sung MH, Hakim O, Oberdoerffer P. A macrohistone variant links dynamic chromatin compaction to BRCA1-dependent genome maintenance. Cell Rep. 2014; 8:1049-1062.
17. Sun $\mathrm{Y}$, Jiang $\mathrm{X}, \mathrm{Xu} \mathrm{Y}$, Ayrapetov MK, Moreau LA, Whetstine JR, Price BD. Histone H3 methylation links DNA damage detection to activation of the tumour suppressor Tip60. Nat Cell Biol. 2009; 11:1376-1382.

18. Baldeyron C, Soria G, Roche D, Cook AJ, Almouzni G. HP1alpha recruitment to DNA damage by p150CAF-1 promotes homologous recombination repair. J Cell Biol. 2011; 193:81-95.

19. Ayoub N, Jeyasekharan AD, Bernal JA, Venkitaraman AR. HP1-beta mobilization promotes chromatin changes that initiate the DNA damage response. Nature. 2008; 453:682-686.

20. Sun Y, Jiang X, Chen S, Fernandes N, Price BD. A role for the Tip60 histone acetyltransferase in the acetylation and activation of ATM. Proc Natl Acad Sci USA. 2005; 102:13182-13187.

21. Xu Y, Sun Y, Jiang X, Ayrapetov MK, Moskwa P, Yang S, Weinstock DM, Price BD. The p400 ATPase regulates nucleosome stability and chromatin ubiquitination during DNA repair. J Cell Biol. 2010; 191:31-43.

22. Murr R, Loizou JI, Yang YG, Cuenin C, Li H, Wang ZQ, Herceg Z. Histone acetylation by Trrap-Tip60 modulates loading of repair proteins and repair of DNA double-strand breaks. Nat Cell Biol. 2006; 8:91-99.

23. Ikura $\mathrm{T}$, Tashiro $\mathrm{S}$, Kakino A, Shima $\mathrm{H}$, Jacob $\mathrm{N}$, Amunugama R, Yoder K, Izumi S, Kuraoka I, Tanaka K, Kimura H, Ikura M, Nishikubo S, et al. DNA damagedependent acetylation and ubiquitination of H2AX enhances chromatin dynamics. Mol Cell Biol. 2007; 27:7028-7040.

24. Tatum D, Li S. Evidence that the histone methyltransferase Dot1 mediates global genomic repair by methylating histone H3 on lysine 79. J Biol Chem. 2011; 286:17530-17535.

25. Wakeman TP, Wang Q, Feng J, Wang XF. Bat3 facilitates H3K79 dimethylation by DOT1L and promotes DNA damage-induced 53BP1 foci at G1/G2 cell-cycle phases. EMBO J. 2012; 31:2169-2181.

26. FitzGerald J, Moureau S, Drogaris P, O'Connell E, Abshiru N, Verreault A, Thibault P, Grenon M, Lowndes NF. Regulation of the DNA damage response and gene expression by the Dot1L histone methyltransferase and the 53Bp1 tumour suppressor. PLoS One. 2011; 6:e14714.

27. Sustackova G, Kozubek S, Stixova L, Legartova S, Matula P, Orlova D, Bartova E. Acetylation-dependent nuclear arrangement and recruitment of BMI1 protein to UVdamaged chromatin. J Cell Physiol. 2012; 227:1838-1850.

28. Kakarougkas A, Ismail A, Chambers AL, Riballo E, Herbert AD, Kunzel J, Lobrich M, Jeggo PA, Downs JA. Requirement for PBAF in transcriptional repression and repair at DNA breaks in actively transcribed regions of chromatin. Mol Cell. 2014; 55:723-732.

29. Vissers JH, van Lohuizen M, Citterio E. The emerging role of Polycomb repressors in the response to DNA damage. J Cell Sci. 2012; 125:3939-3948.

30. Chou DM, Adamson B, Dephoure NE, Tan X, Nottke AC, Hurov KE, Gygi SP, Colaiacovo MP, Elledge SJ. A 
chromatin localization screen reveals poly (ADP ribose)regulated recruitment of the repressive polycomb and NuRD complexes to sites of DNA damage. Proc Natl Acad Sci USA. 2010; 107:18475-18480.

31. O'Hagan HM, Mohammad HP, Baylin SB. Double strand breaks can initiate gene silencing and SIRT1-dependent onset of DNA methylation in an exogenous promoter $\mathrm{CpG}$ island. PLoS Genet. 2008; 4:e1000155.

32. Campbell S, Ismail IH, Young LC, Poirier GG, Hendzel MJ. Polycomb repressive complex 2 contributes to DNA doublestrand break repair. Cell Cycle. 2013; 12:2675-2683.

33. Chang CJ, Yang JY, Xia W, Chen CT, Xie X, Chao CH, Woodward WA, Hsu JM, Hortobagyi GN, Hung MC. EZH2 promotes expansion of breast tumor initiating cells through activation of RAF1-beta-catenin signaling. Cancer Cell. 2011; 19:86-100.

34. Wu Z, Lee ST, Qiao Y, Li Z, Lee PL, Lee YJ, Jiang X, Tan J, Aau M, Lim CZ, Yu Q. Polycomb protein EZH2 regulates cancer cell fate decision in response to DNA damage. Cell Death Differ. 2011; 18:1771-1779.

35. Pfister SX, Ahrabi S, Zalmas LP, Sarkar S, Aymard F, Bachrati CZ, Helleday T, Legube G, La Thangue NB, Porter AC, Humphrey TC. SETD2-dependent histone $\mathrm{H} 3 \mathrm{~K} 36$ trimethylation is required for homologous recombination repair and genome stability. Cell Rep. 2014; 7:2006-2018.

36. Pai CC, Deegan RS, Subramanian L, Gal C, Sarkar S, Blaikley EJ, Walker C, Hulme L, Bernhard E, Codlin S, Bahler J, Allshire R, Whitehall S, Humphrey TC. A histone H3K36 chromatin switch coordinates DNA double-strand break repair pathway choice. Nature communications. 2014; 5:4091.

37. Aymard F, Bugler B, Schmidt CK, Guillou E, Caron P, Briois S, Iacovoni JS, Daburon V, Miller KM, Jackson SP, Legube G. Transcriptionally active chromatin recruits homologous recombination at DNA double-strand breaks. Nat Struct Mol Biol. 2014; 21:366-374.

38. Song Y, Wu F, Wu J. Targeting histone methylation for cancer therapy: enzymes, inhibitors, biological activity and perspectives. J Hematol Oncol. 2016; 9:49.

39. Ahuja N, Sharma AR, Baylin SB. Epigenetic Therapeutics: A New Weapon in the War Against Cancer. Annu Rev Med. 2016; 67:73-89.

40. Daigle SR, Olhava EJ, Therkelsen CA, Basavapathruni A, Jin L, Boriack-Sjodin PA, Allain CJ, Klaus CR, Raimondi A, Scott MP, Waters NJ, Chesworth R, Moyer MP, et al. Potent inhibition of DOT1L as treatment of MLLfusion leukemia. Blood. 2013; 122:1017-1025.

41. McCabe MT, Ott HM, Ganji G, Korenchuk S, Thompson C, Van Aller GS, Liu Y, Graves AP, Della Pietra A 3rd, Diaz E, LaFrance LV, Mellinger M, et al. EZH2 inhibition as a therapeutic strategy for lymphoma with EZH2-activating mutations. Nature. 2012; 492:108-112.
42. Lathia JD, Mack SC, Mulkearns-Hubert EE, Valentim CL, Rich JN. Cancer stem cells in glioblastoma. Genes Dev. 2015; 29:1203-1217.

43. Crespo I, Vital AL, Gonzalez-Tablas M, Patino Mdel C, Otero A, Lopes MC, de Oliveira C, Domingues P, Orfao A, Tabernero MD. Molecular and Genomic Alterations in Glioblastoma Multiforme. Am J Pathol. 2015; 185:1820-1833.

44. Sturm D, Witt H, Hovestadt V, Khuong-Quang DA, Jones DT, Konermann C, Pfaff E, Tonjes M, Sill M, Bender S, Kool M, Zapatka M, Becker N, et al. Hotspot mutations in H3F3A and IDH1 define distinct epigenetic and biological subgroups of glioblastoma. Cancer Cell. 2012; 22:425-437.

45. Li J, Duns G, Westers H, Sijmons R, van den Berg A, Kok K. SETD2: an epigenetic modifier with tumor suppressor functionality. Oncotarget. 2016; 7:50719-50734. doi: 10.18632/oncotarget.9368.

46. Carvalho S, Vitor AC, Sridhara SC, Martins FB, Raposo AC, Desterro JM, Ferreira J, de Almeida SF. SETD2 is required for DNA double-strand break repair and activation of the p53-mediated checkpoint. eLife. 2014; 3:e02482.

47. Sauvageot CM, Weatherbee JL, Kesari S, Winters SE, Barnes J, Dellagatta J, Ramakrishna NR, Stiles CD, Kung AL, Kieran MW, Wen PY. Efficacy of the HSP90 inhibitor 17AAG in human glioma cell lines and tumorigenic glioma stem cells. Neuro Oncol. 2009; 11:109-121.

48. Fernandes ND, Sun Y, Price BD. Activation of the kinase activity of ATM by retinoic acid is required for CREBdependent differentiation of neuroblastoma cells. J Biol Chem. 2007; 282:16577-16584.

49. Pierce AJ, Jasin M. Measuring recombination proficiency in mouse embryonic stem cells. Methods in molecular biology. 2005; 291:373-384.

50. Bennardo N, Cheng A, Huang N, Stark JM. AlternativeNHEJ is a mechanistically distinct pathway of mammalian chromosome break repair. PLoS genetics. 2008; 4:e1000110.

51. Kubicek S, O'Sullivan RJ, August EM, Hickey ER, Zhang Q, Teodoro ML, Rea S, Mechtler K, Kowalski JA, Homon CA, Kelly TA, Jenuwein T. Reversal of H3K9me2 by a small-molecule inhibitor for the G9a histone methyltransferase. Mol Cell. 2007; 25:473-481.

52. Shinkai Y, Tachibana M. H3K9 methyltransferase G9a and the related molecule GLP. Genes Dev. 2011; 25:781-788.

53. Botuyan MV, Lee J, Ward IM, Kim JE, Thompson JR, Chen J, Mer G. Structural basis for the methylation statespecific recognition of histone H4-K20 by 53BP1 and Crb2 in DNA repair. Cell. 2006; 127:1361-1373.

54. Jorgensen S, Schotta G, Sorensen CS. Histone H4 lysine 20 methylation: key player in epigenetic regulation of genomic integrity. Nucleic Acids Res. 2013; 41:2797-2806.

55. MaA, Yu W, Li F, Bleich RM, Herold JM, Butler KV, Norris JL, Korboukh V, Tripathy A, Janzen WP, Arrowsmith CH, Frye SV, Vedadi M, et al. Discovery of a selective, substratecompetitive inhibitor of the lysine methyltransferase 
SETD8. J Med Chem. 2014; 57:6822-6833.

56. Luijsterburg MS, Dinant C, Lans H, Stap J, Wiernasz E, Lagerwerf S, Warmerdam DO, Lindh M, Brink MC, Dobrucki JW, Aten JA, Fousteri MI, Jansen G, et al. Heterochromatin protein 1 is recruited to various types of DNA damage. J Cell Biol. 2009; 185:577-586.

57. Kaidi A, Jackson SP. KAT5 tyrosine phosphorylation couples chromatin sensing to ATM signalling. Nature. 2013; 498:70-74.

58. Sun Y, Xu Y, Roy K, Price BD. DNA damage-induced acetylation of lysine 3016 of ATM activates ATM kinase activity. Mol Cell Biol. 2007; 27:8502-8509.

59. Bakkenist CJ, Kastan MB. DNA damage activates ATM through intermolecular autophosphorylation and dimer dissociation. Nature. 2003; 421:499-506.

60. Ziv Y, Bielopolski D, Galanty Y, Lukas C, Taya Y, Schultz DC, Lukas J, Bekker-Jensen S, Bartek J, Shiloh Y. Chromatin relaxation in response to DNA double-strand breaks is modulated by a novel ATM- and KAP-1 dependent pathway. Nat Cell Biol. 2006; 8:870-876.

61. Greer EL, Shi Y. Histone methylation: a dynamic mark in health, disease and inheritance. Nat Rev Genet. 2012; 13:343-357.

62. Liu W, Deng L, Song Y, Redell M. DOT1L inhibition sensitizes MLL-rearranged AML to chemotherapy. PLoS One. 2014; 9:e98270.

63. Dulev S, Tkach J, Lin S, Batada NN. SET8 methyltransferase activity during the DNA double-strand break response is required for recruitment of 53BP1. EMBO Rep. 2014; 15:1163-1174.

64. Stewart GS, Panier S, Townsend K, Al-Hakim AK, Kolas NK, Miller ES, Nakada S, Ylanko J, Olivarius S, Mendez M, Oldreive C, Wildenhain J, Tagliaferro A, et al. The RIDDLE syndrome protein mediates a ubiquitindependent signaling cascade at sites of DNA damage. Cell. 2009; 136:420-434.

65. Pei H, Zhang L, Luo K, Qin Y, Chesi M, Fei F, Bergsagel PL, Wang L, You Z, Lou Z. MMSET regulates histone H4K20 methylation and 53BP1 accumulation at DNA damage sites. Nature. 2011; 470:124-128.

66. Kudithipudi S, Lungu C, Rathert P, Happel N, Jeltsch A. Substrate specificity analysis and novel substrates of the protein lysine methyltransferase NSD1. Chem Biol. 2014; 21:226-237.

67. White D, Rafalska-Metcalf IU, Ivanov AV, Corsinotti A, Peng H, Lee SC, Trono D, Janicki SM, Rauscher FJ 3rd. The ATM substrate KAP1 controls DNA repair in heterochromatin: regulation by HP1 proteins and serine 473/824 phosphorylation. Molecular cancer research. 2012; 10:401-414.

68. Tang J, Cho NW, Cui G, Manion EM, Shanbhag NM, Botuyan MV, Mer G, Greenberg RA. Acetylation limits 53BP1 association with damaged chromatin to promote homologous recombination. Nat Struct Mol Biol. 2013; 20:317-325.

69. Peng JC, Karpen GH. Heterochromatic genome stability requires regulators of histone $\mathrm{H} 3 \mathrm{~K} 9$ methylation. PLoS Genet. 2009; 5:e1000435.

70. Goodarzi AA, Noon AT, Deckbar D, Ziv Y, Shiloh Y, Lobrich M, Jeggo PA. ATM signaling facilitates repair of DNA double-strand breaks associated with heterochromatin. Mol Cell. 2008; 31:167-177.

71. Di Micco R, Sulli G, Dobreva M, Liontos M, Botrugno OA, Gargiulo G, dal Zuffo R, Matti V, d'Ario G, Montani E, Mercurio C, Hahn WC, Gorgoulis V, et al. Interplay between oncogene-induced DNA damage response and heterochromatin in senescence and cancer. Nat Cell Biol. 2011; 13:292-302.

72. Goodarzi AA, Kurka T, Jeggo PA. KAP-1 phosphorylation regulates $\mathrm{CHD} 3$ nucleosome remodeling during the DNA double-strand break response. Nature structural \& molecular biology. 2011; 18:831-839.

73. Jeggo PA, Downs JA. Roles of chromatin remodellers in DNA double strand break repair. Exp Cell Res. 2014; 329:69-77.

74. Liu S, Ye D, Guo W, Yu W, He Y, Hu J, Wang Y, Zhang L, Liao Y, Song H, Zhong S, Xu D, Yin H, et al. G9a is essential for EMT-mediated metastasis and maintenance of cancer stem cell-like characters in head and neck squamous cell carcinoma. Oncotarget. 2015; 6:6887-6901. doi: 10.18632/oncotarget.3159.

75. Casciello F, Windloch K, Gannon F, Lee JS. Functional Role of G9a Histone Methyltransferase in Cancer. Front Immunol. 2015; 6:487.

76. Hua KT, Wang MY, Chen MW, Wei LH, Chen CK, Ko CH, Jeng YM, Sung PL, Jan YH, Hsiao M, Kuo ML, Yen ML. The H3K9 methyltransferase G9a is a marker of aggressive ovarian cancer that promotes peritoneal metastasis. Mol Cancer. 2014; 13:189.

77. Huang J, Dorsey J, Chuikov S, Perez-Burgos L, Zhang X, Jenuwein T, Reinberg D, Berger SL. G9a and Glp methylate lysine 373 in the tumor suppressor p53. J Biol Chem. 2010; 285:9636-9641. 